\author{
Krzysztof Tomasz WITCZAK \\ Uniwersytet Łódzki \\ (iD https://orcid.org/0000-0001-8895-974X
}

\title{
JAN NEPOMUCEN JÓZEF BRAUN (1926-2015), FILOLOG KLASYCZNY, ORIENTALISTA, KARTWELISTA, SUMEROLOG
}

\author{
JAN NEPOMUCEN JÓZEF BRAUN (1926-2015), CLASSICAL PHILOLOGIST, \\ ORIENTALIST, KARTWELIANIST, SUMEROLOGIST
}

Jan Braun, born on 15th May 1926 in Łódź, studied classical philology and classical archaeology at the University of Lodz (years 1947-1951). His MA thesis (1951) was devoted to the ethnogenesis of the Etruscans. He also worked as junior assistant at the Department of Classical Archaeology, University of Lodz (from May 1949 do September 1950) and later as junior lecturer at the Department of Classical Philology of the same university (from October 1950 to September 1951). In October 1951, Braun left for Georgia in order to complete his doctoral studies. From there he returned to Poland as $\mathrm{PhD}$, specializing in Georgian and other oriental languages, especially the ancient languages of the Near East. In the years 1955-2002, he worked at the University of Warsaw, initially as assistant professor. In 1970, he became associate professor. In 1991, he received the higher doctoral degree (habilitation), and in 1995 he obtained the position of full professor. $\mathrm{He}$ studied the genetic relations of ancient and modern languages, including a suggested Basque-Kartvelian connection. During his habilitation colloquium, he gave an interesting lecture entitled Basic problems of historical-comparative research over the ancient languages of the Mediterranean area (Warsaw, May 28th, 1991), which is presented in Appendix No. 1 (with some comments and bibliographical references). The paper presents Braun's main fields of research and his achievements made in Łódź (Poland), Tbilisi (Georgia) and Warsaw. According to Braun's view, suggested as early as 1951, Etruscan represents an external member of the Anatolian languages (deriving from Luwian), so that it belongs to the Indo-European language family. In his opinion, Basque is a western member of the South Caucasian (or Kartvelian) family.

Keywords: Classical philology in Poland, comparative methodology, diachronic linguistics, Etruscan, history of classics, Indo-European, languages of the ancient world, University of Lodz

Słowa kluczowe: Filologia klasyczna w Polsce, metodologia porównawcza, językoznastwo diachroniczne, etruski, historia klasyki, indoeuropejski, języki świata starożytnego, Uniwersytet Łódzki 
29 czerwca 2015 roku w wieku 89 lat zmarł Jan Braun, emerytowany profesor Uniwersytetu Warszawskiego, lingwista, filolog klasyczny i orientalny, wybitny znawca języka gruzińskiego, badacz języków Wschodu Starożytnego, zwłaszcza języka sumeryjskiego, miłośnik Gruzji, członek zagraniczny Gruzińskiej Akademii Nauk, doktor honoris causa Tbiliskiego Uniwersytetu Państwowego im. Iwane Dżawachiszwilego, uhonorowany nagrodą im. św. Grzegorza Peradze $^{1}$. Mało kto wie, że zmarły uczony urodził się w Łodzi i w Uniwersytecie Łódzkim rozpoczynał karierę akademicką. Dr hab. prof. UW Jan Braun nigdy nie ukrywał swoich związków z Łodzią. Pod koniec lat osiemdziesiątych XX wieku po raz pierwszy zjawiłem się w Zakładzie Wschodu Starożytnego Uniwersytetu Warszawskiego, gdzie umówiłem się na spotkanie z prof. dr hab. Maciejem Popko (1936-2014), znakomitym znawcą języka hetyckiego i języków anatolijskich $^{2}$. Prof. Popko przedstawił mi wówczas dra Jana Brauna jako znakomitego sumerologa i kaukazologa. Dr Braun, gdy tylko dowiedział się, że przyjechałem z Łodzi, od razu podkreślił, że urodził się w Łodzi i że jest absolwentem filologii oraz archeologii klasycznej Uniwersytetu Łódzkiego. Był bardzo zainteresowany łódzką uczelnią oraz aktualnymi losami łódzkiej filologii klasycznej ${ }^{3}$, pytał m.in. o mojego opiekuna naukowego prof. Dankę, filologa klasycznego i językoznawcę, prosił także o przekazanie mu pozdrowień i ukłonów. Prof. dr hab. Ignacy Ryszard Danka (podówczas już pracownik samodzielny ze stopniem doktora habilitowanego uzyskanym w 1984 r., zatrudniony na stanowisku docenta) potwierdził, że podczas swoich studiów filologicznych na Uniwersytecie Warszawskim (w latach 1957-1962) uczestniczył w zajęciach „,wstępu do językoznawstwa ogólnego", które prowadził wówczas bardzo młody doktor Jan Braun (rodem z miasta Łodzi). Pamiętam, że ogromnie zafrapował mnie fakt, że Jan Braun gruntownie rozszerzył zainteresowania i wyszedłszy od języków klasycznych (greki i łaciny) podążył w kierunku szeroko pojętej orientalistyki i badań porównawczych odległych geograficznie języków, np. języka etruskiego i luwijskiego, języka baskijskiego i gruzińskiego, języka sumeryjskiego i tybetańskiego.

Uważam, że warto na łamach czasopisma „Collectanea Philologica” przedstawić losy zmarłego łodzianina i jego związki z Uniwersytetem Łódzkim. Kim był Jan Braun? Jak układała się jego kariera akademicka? Jaki miał dorobek naukowy?

1 Nekrologi zmarłego: Przegląd Orientalistyczny 2015, 3-4 (255-256), 307; „In memoriam. Jan Braun (15 V 1926-29 VI 2015)"; Pro Georgia 27, 2017, 297-299 (fot.). Zob. też powiadomienia internetowe: http://zws.orient.uw.edu.pl/wp-content/uploads/2015/05/JB.pdf [dostęp 20.03.2021]. Szerzej postać dra hab. prof. UW Jana Brauna i jego dorobek naukowy przedstawia Olga Drewnowska (2018: 133-139).

${ }^{2}$ Postać i dorobek naukowy wybitnego hetytologa polskiego prezentuje Piotr Taracha (2014: 104-108). Zob. też Taracha, Głazek 2014: 109-122.

${ }^{3}$ Dzieje łódzkiej filologii klasycznej zostały udokumentowane w kilku opracowaniach specjalistycznych (Jędrzejczak, Pacho 2003: 71-85; Rządkiewicz 2005: 4-21). 
Urodził się 15 maja 1926 roku w Łodzi ${ }^{4}$ w rodzinie inteligenckiej jako najmłodsze dziecko Jana Tymoteusza Brauna ${ }^{5}$ i Anny z Żylińskich herbu Ciołek. Na chrzcie nadano mu trzy imiona: Jan Nepomucen Józef ${ }^{6}$, ale wszyscy wołali nań „Jaś” lub „Jasio”, jak to uwieczniła jego starsza siostra Michalina we wspomnieniach z czasów dzieciństwa?

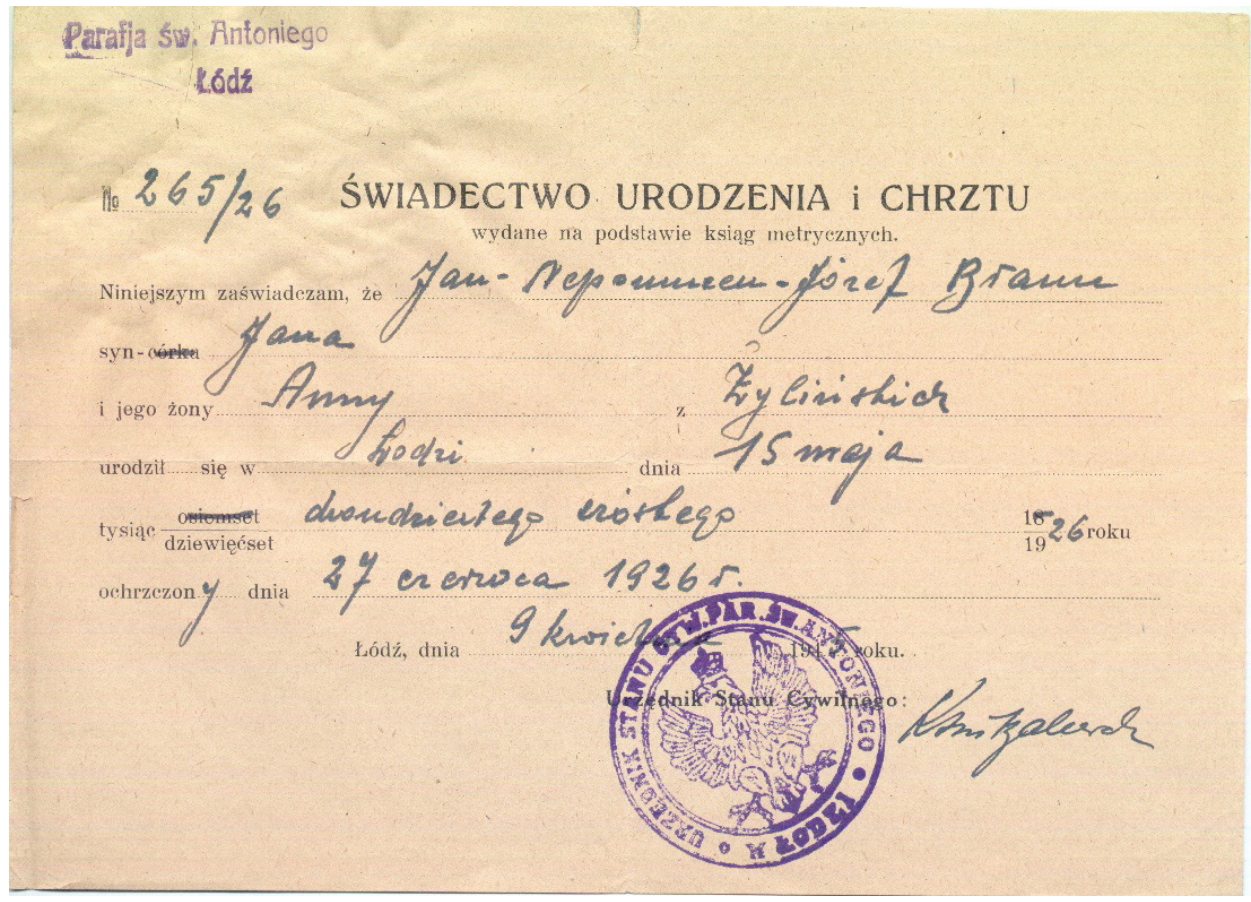

Ilustr. 1. Świadectwo urodzenia i chrztu Jana Nepomucena Józefa Brauna.

Źródło: Archiwum Uniwersytetu Łódzkiego.

Ojciec był nauczycielem szkół powszechnych, od grudnia 1926 r. kierownikiem Powszechnej Szkoły Publicznej nr 30 w Łodzi przy ul. Wspólnej 5/7. Matka Anna była polonistką, która zrezygnowała z pracy nauczycielskiej i poświęciła

${ }^{4}$ Dokładną datę urodzenia Jana Nepomucena Józefa Brauna podaje m.in. jego starsza siostra Michalina Wisłocka: „Urodził się 15 maja 1926 roku, trochę nie planowany” (Wisłocka 1998: 61).

${ }^{5}$ Postać Jana Tymoteusza Brauna, łódzkiego polonisty, pedagoga, dyrektora szkoły i poety, przystępnie przedstawia Kowalski (2007: 7-8).

${ }^{6}$ Kopia aktu chrztu i urodzenia Jana Nepomucena Józefa Brauna znajduje się w zbiorach Archiwum Uniwersytetu Łódzkiego: AUŁ, Akta osobowe nr 227; Akta studenckie nr 1430/H. Należy podkreślić, że w innych oficjalnych dokumentach zgromadzonych w AUŁ pojawiają się tylko dwa imiona. Na teczce $\mathrm{z}$ aktami również napisano: Jan Józef Braun.

${ }^{7}$ Wisłocka podkreśla, że ,Jasio urodził się prawie niezauważalnie [...] I jakoś nie miał przezwiska, został ze swoim imieniem na całe życie" (Wisłocka 1998: 61). 
się wychowaniu trójki dzieci: Michaliny Anny (zwanej „Malinką”, ur. 1 lipca 1921 r.), Andrzeja (zwanego przez siostrę „Bratkiem”, ur. 19 sierpnia 1923 r.) i Jana Nepomucena Józefa (czyli „Jasia”). Cała trójka osiągnęła sukces zawodowy i osobisty. Michalina Anna z Braunów Wisłocka (1921-2005) zdobyła stopień doktora medycyny, została cenioną specjalistką w zakresie ginekologii, cytologii i seksuologii, a powszechną sławę przyniosła Jej wydana w 1976 roku książka pt. Sztuka kochania. Andrzej Braun (1923-2008) został uznanym polskim pisarzem, poetą i reportażystą, prezesem Stowarzyszenia Pisarzy Polskich (w latach 1990-1993). Jan Braun wybrał z kolei karierę akademicką i osiągnął na tej drodze niewątpliwe sukcesy.

Pierwsze nauki mały „Jaś” pobierał pod okiem matki, a następnie w latach 1933-1939 uczęszczał do Powszechnej Szkoły Publicznej nr 30 im. św. Stanisława Kostki w Łodzi, której kierownikiem był jego ojciec Jan Tymoteusz Braun. Po ukończeniu sześciu klas szkoły powszechnej (31 VI 1939 r.) zamierzał kontynuować naukę w Państwowym Gimnazjum Męskim nr 38 im. Stefana Żeromskiego w Łodzi. Wybuch wojny i okupacja uniemożliwiła mu jednak dalszą naukę. Do łódzkiego gimnazjum uczęszczał przez około trzy miesiące (od 15 września 1939 do 10 grudnia 1939 r.). Wcielenie Łodzi do „Kraju Warty” wywołało ogromną falę wysiedleń ludności polskiej z Łodzi do Generalnego Gubernatorstwa. 11 grudnia 1939 roku pięcioosobowa rodzina Braunów trafiła do obozu przejściowego w Radogoszczu, a następnie została przymusowo wysiedlona do Małopolski. Ich nowym domem stała się wieś Narama koło Krakowa, gdzie ojciec Jan Tymoteusz otrzymał posadę nauczyciela w szkole powszechnej. Nastoletni Jan Braun kontynuował wówczas naukę pod okiem ojca i rozwijał swoje zainteresowania językami obcymi. Głównym problemem był jednak brak odpowiednich podręczników do nauki. Ale i na to w trudnych warunkach okupacyjnych (na wysiedleniu) znalazła się odpowiednia rada: ojciec poświęcił złote mostki, by rodzinie i synom sprezentować potrzebne rzeczy. Wspomina o tym córka Michalina Wisłocka:

„Dywagacje prowadzące donikąd przerwał uśmiech szczerbatego ojca, który na przednówku wybrał się do Krakowa, żeby zdjąć złote mosty z zębów.

- Jezu, Janek, coś ty zrobił! - krzyknęła matka na jego widok.

Ale za chwilę wszyscy krzyczeli, że ,z radości drży dom cały, tata niesie wiktuały”. Jasio kupił sobie słownik i gramatykę grecką, Iliadę i Odyseję po grecku oraz słownik łaciński i Ody Horacego i już po kilku tygodniach nauki bez kłopotu czytał greckie i łacińskie teksty. Przy tej okazji zakochał się na zabój w Horacym i wszystkie jego wiersze wykuł na pamięć. To oczarowanie pozostało mu na całe życie. Andrzej z kolei nabył kilka tomów Conrada i całe późniejsze życie próbował naśladować jego styl we własnych książkach" (Oziminkowski 2014: 72).

Podczas okupacji nastoletni Jan Braun nie tylko pogłębiał swoją wiedzę w zakresie języków klasycznych, ale też pracował jako robotnik rolny. Uczestniczył ponadto w tajnym nauczaniu młodzieży wiejskiej. W roku 1944 wstąpił do Batalionów Chłopskich i przyjął pseudonim „Jodła”. Służył jako strzelec w stop- 
Jan Nepomucen Józef Braun (1926-2015), filolog klasyczny, orientalista, kartwelista... 207

niu szeregowca w plutonie „Mewa” terenowych oddziałów Armii Krajowej w powiecie krakowskim ${ }^{8}$.

Po ustąpieniu okupanta, w kwietniu 1945 roku, powrócił wraz z ojcem ${ }^{9}$ i matką do Łodzi i zamieszkał w budynku przy ul. Wspólnej 5/7 m. 2. Niezwłocznie przystąpił do uzupełnienia edukacji przerwanej przez wybuch drugiej wojny światowej. W przeciągu dwóch lat nadrobił zaległości spowodowane drugą wojną światową: ukończył dwie klasy gimnazjum (tj. trzecią i czwartą klasę) oraz dwie klasy liceum im. Stefana Żeromskiego w Łodzi. 22 lutego 1947 roku Jan Braun otrzymał świadectwo dojrzałości.

W tymże roku rozpoczął studia na Wydziale Humanistycznym Uniwersytetu Łódzkiego na kierunku filologii klasycznej i archeologii klasycznej (śródziemnomorskiej). Otrzymał indeks studencki o numerze albumu 1430/H. Nie należy się dziwić, że dwudziestoletni Jan Braun wybrał takie właśnie studia, skoro - jak twierdzi starsza siostra Michalina Wisłocka - od lat był zakochany w języku greckim i łacińskim, w poezji Homera i Horacego. Należy pieczołowicie odnotować, że Katedra Filologii Klasycznej oraz Katedra Archeologii Klasycznej już 1945 r. funkcjonowały na Wydziale Humanistycznym Uniwersytetu Łódzkiego. Twórcą i kierownikiem pierwszej był prof. Jan Oko $(1875-1946)^{10}$, a na czele drugiej stał prof. dr Rajmund Gostkowski (1885-1966), który po niespodziewanej śmierci Jana Oki (zm. 8 września 1946 r. w Zakopanem) przez niemal rok pełnił funkcję kuratora Katedry (później Zakładu) Filologii Klasycznej ${ }^{11}$. Obie Katedry mieściły się w dawnej fabrykanckiej willi przy ul. M. Curie-Skłodowskiej 11 (obecnie mieści się tu Łódzkie Towarzystwo Naukowe). Na piętrze owej willi znajdowało się mieszkanie prof. Gostkowskiego, a na parterze odbywały się ćwiczenia oraz wykłady dla studentów filologii klasycznej i archeologii klasycznej. Studenci obu kierunków dość swobodnie mogli chodzić na zajęcia przeznaczone dla drugiej specjalności. Od archeologów klasycznych wymagano bowiem specjalistycznego wykształcenia w zakresie filologii klasycznej i kultury starożytnej Grecji i Rzymu. Co więcej, studenci filologii klasycznej i archeologii śródziemnomorskiej mogli korzystać z prywatnej (rozlokowanej na parterze) biblioteki prof. Gostkowskiego, która zawierała nie tylko literaturę archeologiczną, ale także liczne wydania autorów klasycznych, którymi nie dysponowała tworząca się dopiero Biblioteka Uniwersytetu Łódzkiego (Rządkiewicz 2005: 5).

${ }^{8}$ W 1946 roku dwudziestoletni Jan Braun wstąpił do Związku Uczestników Walki Zbrojnej o Niepodległość i Demokrację, później funkcjonującego pod nazwą Związku Bojowników o Wolność i Demokrację (nr legitymacji 20601).

${ }^{9}$ Po drugiej wojnie światowej Jan Tymoteusz Braun pracował w Kuratorium Okręgu Szkolnego Łódzkiego w Łodzi jako urzędnik Wydziału Planowania. Matka nie podjęła pracy.

${ }^{10}$ Oświecimski 1978: 670-672; Starnawski 1998: 338-340; 2003: 87-90.

${ }^{11}$ Zarówno Jan Oko, jak i Rajmund Gostkowski w okresie dwudziestolecia międzywojennego byli profesorami Uniwersytetu Stefana Batorego w Wilnie. Ich łódzka współpraca była zatem kontynuacją z czasów wileńskich. 


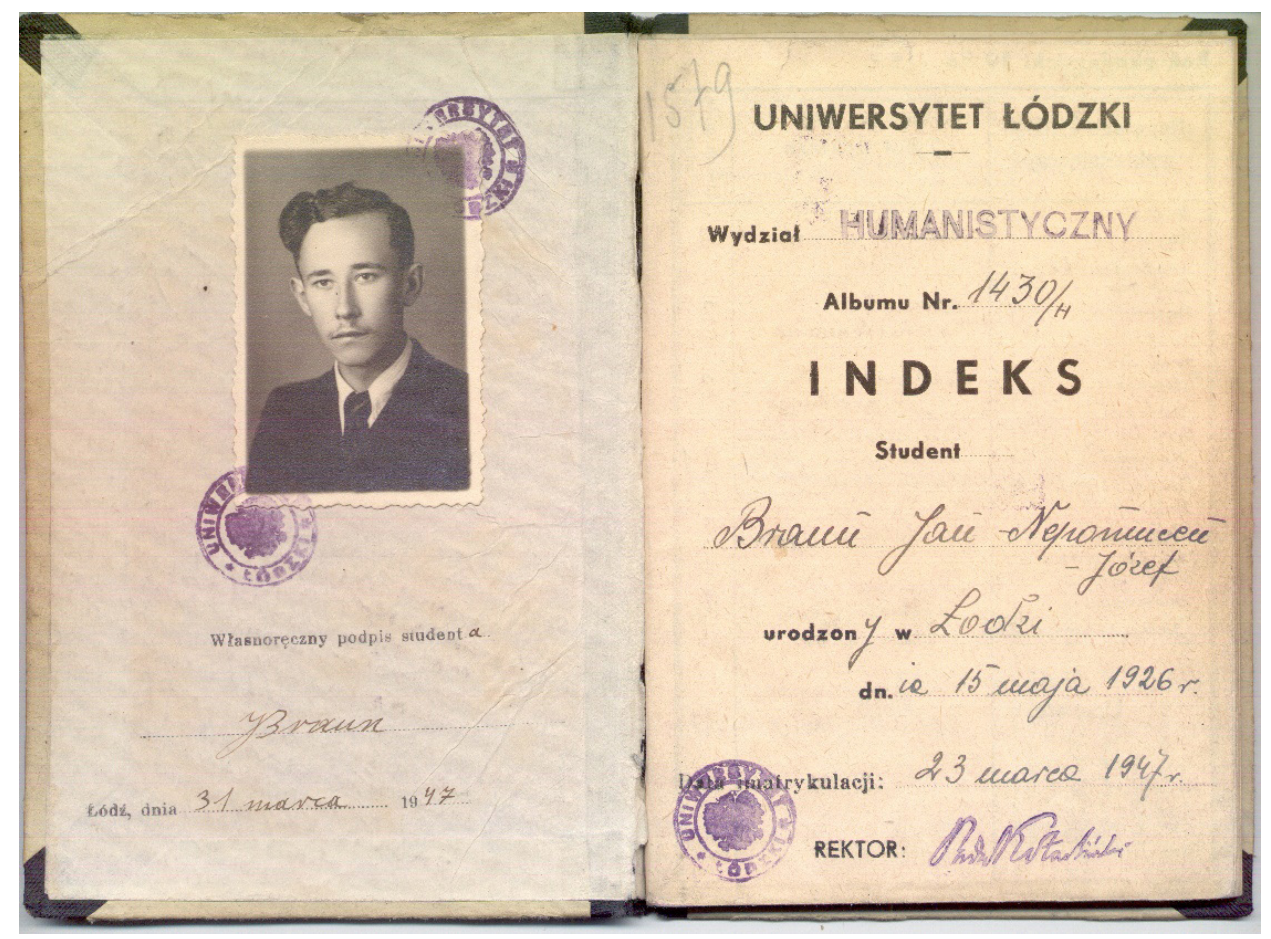

Ilustr. 2. Indeks studencki Jana Brauna nr 1430/H. Strona z fotografią i podpisem. Źródło: Archiwum Uniwersytetu Łódzkiego.

W latach studenckich (1947-1951) Jan Braun brał czynny udział w pracach Koła Studentów Filologii Klasycznej Uniwersytetu Łódzkiego, pełniąc m.in. funkcję prezesa i sekretarza tejże organizacji, a także w pracach Stowarzyszenia Kół Naukowych Wydziału Humanistycznego UŁ (Rządkiewicz 2005: 31). Niestety, na kierunku filologii klasycznej Jan Braun nie mógł rozwijać swoich zainteresowań językoznawczych, gdyż w czasie jego studiów (1947-1951) łódzka filologia klasyczna była całkowicie zdominowana przez literaturoznawców ${ }^{12}$. Na czele Katedry (potem Zakładu) stał wówczas dr hab. (od 1948 r. prof. nadzw.) Jerzy Edward Schnayder (1895-1974), którego zainteresowania badawcze dotyczyły greckiej periegezy, antycznej epistolografii oraz twórczości Teofrasta. Miał on do pomocy mgra Mieczysława Michała Smokowskiego (1906-1956), który

${ }^{12}$ Łódzka szkoła językoznawczo-religioznawcza, działająca w zakresie kultur i języków klasycznych oraz indoeuropejskich, została stworzona przez prof. dra hab. Ignacego Ryszarda Dankę, który pracował w Katedrze Filologii Klasycznej w latach 1962-2007. Spośród licznych uczniów prof. Danki warto wymienić m.in. dra hab. prof. UŁ Zbigniewa Danka, dr hab. Idalianę Kaczor, dr hab. prof. UŁ Elwirę Kaczyńską, dr Annę Maciejewską, dr Tamarę Roszak, dr hab. Joannę Rybowską, prof. dra hab. Krzysztofa Tomasza Witczaka. 
Jan Nepomucen Józef Braun (1926-2015), filolog klasyczny, orientalista, kartwelista... 209

zajmował się literaturą rzymską, głównie działalnością polityczną i literacką Marka Tulliusza Cycerona (Rządkiewicz 2005: 96-97).

Zajęcia zlecone na filologii klasycznej prowadził także doc. dr Marian Michał Golias (1887-1966), który w latach 1946-1951 pracował jako profesor kontraktowy w Państwowej Wyższej Szkole Pedagogicznej w Łodzi, pełniąc w latach 1948-1950 funkcję prorektora PWSP. Niestety, prof. Golias, choć był współautorem gramatyki greckiej i szkolnej gramatyki łacińskiej, nie miał zainteresowań ściśle lingwistycznych. Był przede wszystkim specjalistą z zakresu metodyki oraz dydaktyki języka greckiego i łacińskiego, znawcą literatury greckiej i thumaczem bajek Ezopa.

Prof. Schnayder zrezygnował z usług mgr Jadwigi Kruszewskiej oraz mgra Leona Tadeusza Błaszczyka ${ }^{13}$, którzy byli pracownikami Katedry Filologii Klasycznej w latach 1945-1947 (przyjętymi do pracy naukowo-dydaktycznej przez prof. Jana Oko, założyciela KFK UŁ, a później podlegającymi kuratorowi Katedry prof. R. Gostkowskiemu). W efekcie Jan Braun, nie mogąc rozwijać zainteresowań językoznawczych na kierunku filologii klasycznej, zbliżył się prof. dra Rajmunda Gostkowskiego, kierownika Katedry Archeologii Klasycznej, który świetnie władał kilkoma językami starożytnymi i nowożytnymi, między innymi językiem nowogreckim. Prof. Gostkowski był zainteresowany kwestią pochodzenia Etrusków i ich niezrozumiałego języka, toteż zaproponował zdolnemu adeptowi filologii klasycznej podjęcie tej złożonej i wysoce kontrowersyjnej problematyki.

1 maja 1949 r. Jan Braun (jeszcze jako student filologii klasycznej) został zatrudniony na pół etatu w charakterze zastępcy młodszego asystenta w Katedrze Archeologii Klasycznej Uniwersytetu Łódzkiego ${ }^{14}$. 1 października 1950 r. otrzymał angaż roczny (do 31 sierpnia 1951 r.) na etat młodszego asystenta w Zakładzie Filologii Klasycznej UŁ z pensum 30 godzin tygodniowo. Zmiana zatrudnienia wiązała się z faktem, że prof. dr Rajmund Gostkowski, kierownik Katedry Archeologii Klasycznej UŁ i bezpośredni przełożony Jana Brauna, został na początku lat pięćdziesiątych aresztowany przez władze komunistyczne za działalność w strukturach

${ }^{13}$ Z dniem 1 czerwca 1947 r. L.T. Błaszczyk został przeniesiony ze stanowiska starszego asystenta Zakładu Filologii Klasycznej UŁ na stanowisko bibliotekarza naukowego w Bibliotece Uniwersytetu Łódzkiego. Po uzyskaniu stopnia doktora filozofii w zakresie filologii klasycznej oraz historii kultury (1950) został zatrudniony na Wydziale Filozoficzno-Historycznym UŁ i mianowany kierownikiem Zakładu Historii Starożytnej w Katedrze Historii Powszechnej (1953), a w r. 1956 awansowany na stanowisko docenta. W latach 1964-1966 był dziekanem Wydziału Filozoficzno-Historycznego, a następnie dyrektorem Instytutu Historii UŁ (1966-1968). W 1968 r. na skutek wydarzeń marcowych opuścił Polskę i wyjechał do Stanów Zjednoczonych. Do Polski powrócił w 1989 roku (Rządkiewicz 2005: 27-29; Kozłowski 2017: 277-279).

${ }^{14}$ Do obowiązków zastępcy młodszego asystenta należały m.in. pięciogodzinne dyżury biblioteczne. Studenci mogli korzystać z zasobów biblioteki prof. Gostkowskiego podczas obecności pracownika Katedry Filologii Klasycznej lub Katedry Archeologii Klasycznej (uwaga na podstawie wspomnień prof. dr hab. Bohdana Wiśniewskiego, podówczas studenta filologii klasycznej Uniwersytetu Łódzkiego). Jan Braun pobierał pensję w wysokości 13.200 złotych. 
Armii Krajowej na Wileńszczyźnie ${ }^{15}$. Aresztowanie prof. Gostkowskiego stało się powodem zlikwidowania Katedry Archeologii Klasycznej UŁ w 1950 r., dlatego na początku roku akademickiego 1950/1951 Jan Braun został przeniesiony na etat zastępcy młodszego asystenta w Zakładzie Filologii Klasycznej UŁ. Jednak i tu nie mógł zadomowić się na długo, gdyż w 1950 roku podjęto decyzję o likwidacji kierunków „burżuazyjnych” wykładanych na Uniwersytecie Łódzkim, który miał - w „genialnej” wizji władz komunistycznych - stać się wiodącym uniwersytetem robotniczym. W efekcie tej nieprzemyślanej decyzji na łódzkiej uczelni zaprzestano naboru na studia magisterskie filologii angielskiej, germańskiej, klasycznej i romańskiej. Studenci tych specjalności filologicznych, którzy rozpoczęli studia w roku akademickim 1949/1950 zakończyli studia w roku 1953. Po zakończonym cyklu edukacyjnym prof. Jerzy Schnayder, kierownik Zakładu Filologii Klasycznej UŁ, opuścił Uniwersytet Łódzki i przeniósł się na początku roku akademickiego 1953/54 na Uniwersytet Wrocławski.

10 października 1951 r. Jan Braun uzyskał tytuł magistra filozofii w zakresie archeologii klasycznej (nr dyplomu 515), przedstawiwszy pracę dyplomową pt. Etnogeneza Etrusków w świetle danych archeologicznych ${ }^{16}$. Oficjalnym promotorem był prof. dr hab. Konrad Jażdżewski (1908-1985) ${ }^{17}$, faktycznym zaś prof. dr Rajmund Gostkowski (usunięty z łódzkiej uczelni przez ówczesne władze komunistyczne).

W październiku 1951 świeżo wypromowany mgr Jan Braun został wysłany na aspiranturę (tj. czteroletnie studia doktoranckie) do ówczesnego ZSRR. Podczas pobytu w Gruzji poznał języki kaukaskie i orientalne, zwłaszcza język gruziński i starożytne języki Bliskiego Wschodu (m.in. urartyjski). W latach 1952-1955 pracował jako aspirant (tj. doktorant) Uniwersytetu Państwowego im. Józefa W. Stalina w Tbilisi. Uczestniczył w wielu aspektach działalności naukowej uczelni, m.in. latem r. 1952 we wsi Mažvrisremi prowadził badania nad słownictwem dialektu kartlijskiego języka gruzińskiego. W roku 1954 Jan Braun wydał drukiem (po rosyjsku) dwie pierwsze prace naukowe, wymagane wobec aspiranta przed przystąpieniem do obrony kandydackiej, które od razu świadczyły o rozległości jego zainteresowań - od języka baskijskiego poprzez urartyjski aż po języki kaukaskie, zwłaszcza kartwelskie ${ }^{18} .2$ lipca 1955 w Uniwersytecie Państwowym im. Józefa W. Stalina w Tbilisi (Gruzja) Jan Braun uzyskał stopień kandydata nauk, tj. rosyjski odpowiednik stopnia doktora (w zakresie nauk humanistycznych) na podstawie dysertacji zatytułowanej Многоличность (полипрозопия) грузинского глагола [Wieloosobowość (poliprozopia) czasownika gruzińskiego], napisanej pod kierun-

${ }^{15}$ Zob. Kita, Pytlas 2005: 86-88, zwł. 87.

${ }^{16}$ Niestety, w Archiwum UŁ nie ma obecnie egzemplarza pracy magisterskiej Jana Józefa Brauna. W aktach znajduje się jedynie notatka z 1956 roku, że praca magisterska została „wypożyczona” przez autora.

${ }^{17}$ Zob. Kita, Pytlas 2005: 156-158.

${ }^{18}$ Braun 1954: 40-42; Braun, Klimov 1954: 49-52. 
kiem gruzińskiego promotora - prof. dr hab. Akaki Szanidze ${ }^{19}$. Oficjalne zatwierdzenie tego stopnia naukowego nastąpiło 17 października 1955 roku.

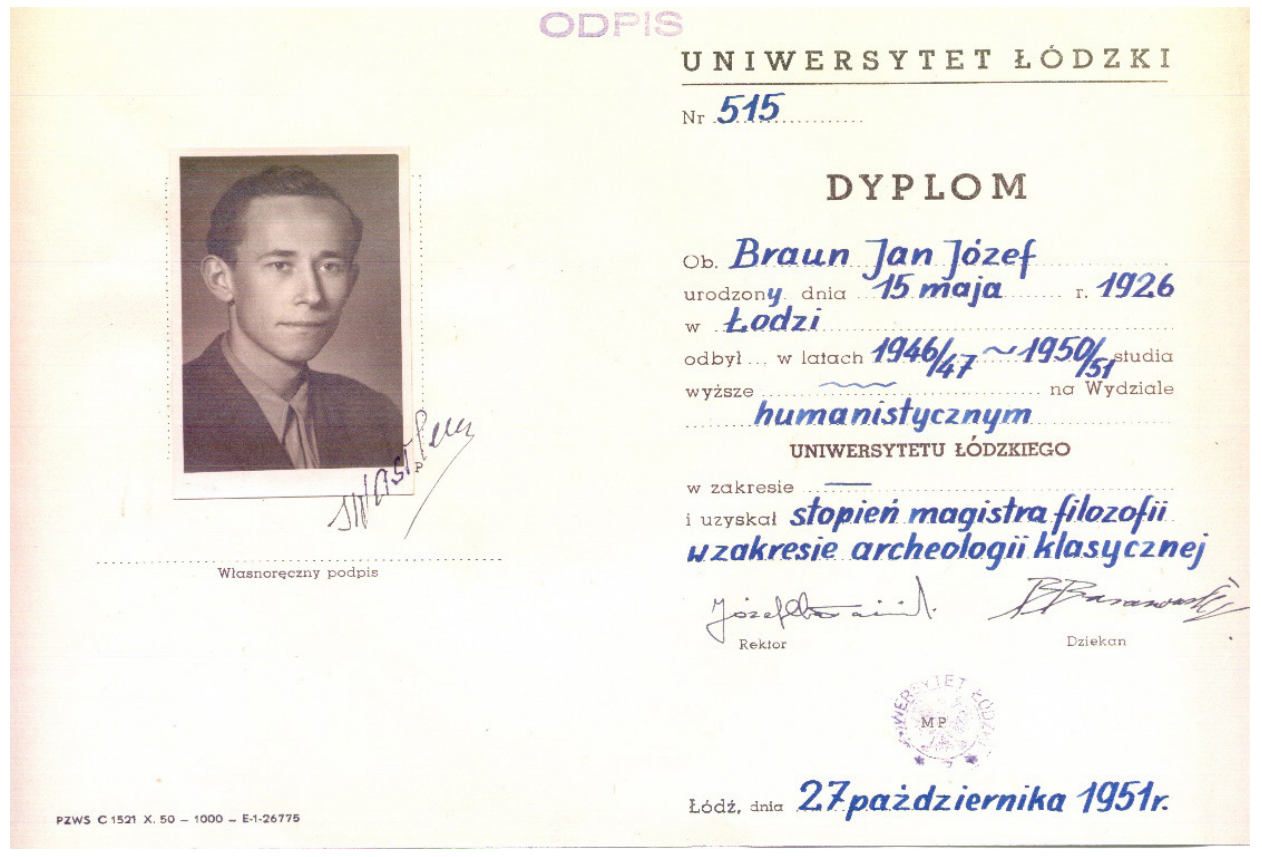

Ilustr. 3. Dyplom ukończenia studiów magisterskich (odpis z fotografią).

Źródło: Archiwum Uniwersytetu Łódzkiego.

Już 15 lipca 1955 roku Jan Braun powrócił do kraju i od 1 września 1955 roku został zatrudniony na stanowisku adiunkta w Katedrze Językoznawstwa Ogólnego Uniwersytetu Warszawskiego. Chociaż na aspiranturę do ówczesnego Związku Socjalistycznych Republik Radzieckich wyjechał jako świeżo wypromowany archeolog klasyczny (śródziemnomorski), mający także absolutorium w zakresie filologii klasycznej, to do Polski powrócił jako językoznawca, specjalista od języka gruzińskiego, znawca starożytnych języków Bliskiego Wschodu, a nadto jako zdeklarowany orientalista, zakochany w Gruzji i krajach Kaukazu. Nic dziwnego zatem, że dr Jan Braun już w roku 1955 wstąpił do Polskiego Towarzystwa Orientalistycznego i w latach 1956-1990 czynnie działał w Zarządzie Głównym PTO ${ }^{20}$.

${ }^{19}$ Drukiem ukazał się tylko rosyjski piętnastostronicowy autoreferat dysertacji kandydackiej (Braun 1955). Tekst tego autoreferatu został przetłumaczony po prawie 50 latach na język polski (Braun 2002-2003: 19-35).

${ }^{20} \mathrm{Na}$ łamach „Przeglądu Orientalistycznego”, czasopisma wydawanego przez Polskie Towarzystwo Orientalistyczne, Jan Braun opublikował - o ile prawidłowo ustaliłem - tylko jedną pracę poświęconą poezji gruzińskiej (Braun 1959: 195-200). 
Od roku 1956 (aż do roku 1980) prowadził wykład pt. Wstęp do językoznawstwa ogólnego, przeznaczony dla studentów różnych kierunków, w tym dla studentów I roku orientalistyki. W roku 1958 poprowadził z kolei wykład pt. Wybrane zagadnienia z językoznawstwa indoeuropejskiego dla studentów IV i V roku neofilologii i slawistyki. W latach 1961-1964 uczestniczył w zajęciach prof. dra Rudolfa Ranoszka z zakresu hetytologii i sumerologii, pogłębiając swoją wiedzę w tym zakresie. Od roku 1962 prowadził lektorat języka gruzińskiego przy Instytucie Orientalistycznym UW. W roku 1964 przeniósł się na własną prośbę na stanowisko adiunkta Katedry Filologii Wschodu Starożytnego UW. Od 1 X 1967 pracował na stanowisku starszego wykładowcy w owej Katedrze (od r. 1968 w Zakładzie Filologii Wschodu Starożytnego). Decyzją Ministra Oświaty i Szkolnictwa Wyższego dr Jan Braun został mianowany docentem Instytutu Orientalistycznego na Wydziale Filologii Obcych Uniwersytetu Warszawskiego z dniem 1 czerwca 1970 roku. Mianowanie zostało bez wątpienia wywołane odczuwalnym brakiem pracowników samodzielnych, co z kolei było wynikiem wydarzeń marcowych 1968 roku, prowadzących do usunięcia z uczelni profesorów żydowskiego pochodzenia. W latach 1970-1975 doc. dr Jan Braun pełnił funkcję kierownika Zakładu Filologii Wschodu Starożytnego Instytutu Orientalistycznego UW. W 1973 r. został powołany do Komitetu Nauk Orientalistycznych PAN. W latach 1976 i 1977 przebywał przez 4 miesiące w Gruzji, gdzie w Państwowym Uniwersytecie w Tbilisi jako „visiting professor” prowadził wykład ze wstępu do baskologii ${ }^{21}$. W 1986 r. został członkiem Societas Caucasologica Europaea. Na stanowisku docenta pracował do roku 1995. W tymże roku (1 X 1995 r.) mając 69 lat Jan Braun otrzymał stanowisko profesora nadzwyczajnego Uniwersytetu Warszawskiego.

6 października 1990 roku doc. dr Jan Braun złożył podanie o wszczęcie przewodu habilitacyjnego na podstawie cyklu 8 publikacji dotyczących badań nad pokrewieństwem języków południowokaukaskich i języka baskijskiego. Cykl obejmował podręcznik wydany w języku gruzińskim pt. Wstęp do baskologii (liczył on 104 stronice) oraz siedem artykułów zagranicznych opublikowanych w latach 1981-1988. Recenzentami w przewodzie habilitacyjnym byli: prof. Adam Weinsberg (Uniwersytet Warszawski), prof. Zurab Czumburidze (Tbilisi, Gruzja) i prof. Dominique Peillen (Pau, Francja). Wszyscy recenzenci pozytywnie ocenili dorobek i osiągnięcie naukowe habilitanta, chociaż każdy z recenzentów spoglądał na dokonania habilitanta $\mathrm{z}$ innego punktu widzenia. Prof. Weinsberg poprzez pryzmat językoznawstwa ogólnego, prof. Czumburidze z punktu widzenia kartwelologii, a prof. Peillen wskazywał na osiągnięcia Jana Brauna z zakresie badań nad pochodzeniem języka Basków.

${ }^{21}$ Rezultatem tego pobytu była monografia wydana w języku gruzińskim pt. Basḳologiis šesavali [Wstęp do baskologii], licząca 104 stronice (Braun 1984). Na stronie redakcyjnej widnieje dodatkowa informacja w języku rosyjskim: Ян Браун, Введение в баскологию (на грузинском языке), Издательство Тбилисского университета, Тбилиси 1984. 
Jan Nepomucen Józef Braun (1926-2015), filolog klasyczny, orientalista, kartwelista... 213

Warto zacytować protokół z posiedzenia pięciosobowej Komisji Wydziałowej z dnia 8 maja 1991 roku, dotyczący dopuszczenia doc. dra Jana Brauna do kolokwium habilitacyjnego ${ }^{22}$ :

Komisja zapoznała się z recenzjami przedstawionymi przez prof. Zuraba Czumburidze, prof. Dominique Peillen i prof. dr[a] hab. Adama Weinsberga i stwierdziła, że są one jednoznacznie pozytywne. Recenzenci podkreślają duże znaczenie prowadzonych przez doc. Jana Brauna od lat badań na[d] kwestią ewentualnego pokrewieństwa języków kartwelskich z językiem baskijskim. Jest to zagadnienie bardzo trudne i jego rozstrzygnięcie byłoby zdaniem prof. Weinsberga „odkryciem językoznawczym na wielką skalę”.

Prof. Weinsberg twierdzi, że „rozległa erudycja doc. Brauna i precyzja jego metod badawczych stawiają go w skali międzynarodowej w rzędzie najwybitniejszych językoznawców o takich rzadkich zainteresowaniach". Podkreśla także osiągnięcia dydaktyczne doc. Brauna, który wypromował jednego doktora sumerologii, jest promotorem następnej rozprawy doktorskiej z tej dziedziny oraz wykształcił sześciu magistrów z zakresu sumerologii i baskologii.

Prof. Czumburidze, zajmując się głównie kartwelską stroną porównań w badaniach habilitanta, stwierdza, że ,prace naukowe Jana Brauna z dziedziny baskijsko-kaukaskich stosunków językowych są poważnym wkładem do danej sfery badań”.

Natomiast prof, Peillen, koncentrując swoje uwagi na baskijskich aspektach prac doc. Brauna, podkreśla rzetelność jego badań i poważny wkład do naszej wiedzy o powinowactwie badanych języków.

Biorąc po uwagę oceny zawarte $\mathrm{w}$ recenzjach Komisja występuje $\mathrm{z}$ wnioskiem o dopuszczenie doc. Jana Brauna do kolokwium habilitacyjnego.

Podczas kolokwium habilitacyjnego, które odbyło się 28 maja 1991 roku, doc. dr Jan Braun wygłosił wykład pt. Podstawowe problemy badań historyczno-porównawczych nad językami starożytnego Śródziemnomorza ${ }^{23}$ i odpowiedział na pytania recenzentów i członków Wydziału Neofilologii Uniwersytetu Warszawskiego. Nie wszyscy byli usatysfakcjonowani otrzymanymi odpowiedziami. Głosowanie też nie było jednomyślne. Ostatecznie jednak kolokwium zakończyło się dla habilitanta pomyślnie i dr Jan Braun otrzymał stopień doktora habilitowanego w zakresie językoznawstwa (językoznawstwa kaukaskiego) za ,jednotematyczny cykl publikacji dotyczących badań pokrewieństwa genetycznego języków kartwelskich i języka baskijskiego", nadany uchwałą Rady Wydziału Neofilologii Uniwersytetu Warszawskiego w dniu 28 maja 1991 roku. Centralna Komisja do Spraw Tytułu Naukowego i Stopni Naukowych zatwierdziła tę decyzję w roku następnym (24 II 1992). Sześć lat później (1998) dr hab. prof. UW Jan Braun wydał w Wydawnictwie Akademickim Dialog antologię

${ }^{22}$ Archiwum Uniwersytetu Warszawskiego, Akta przewodów habilitacyjnych, sygn. WNF-hab2.88, k. 19. W posiedzeniu Komisji udział brali: dziekan Wydziału Neofilologii UW prof. dr hab. Andrzej Sieroszewski (jako przewodniczący), oraz profesorowie tytularni Andrzej Bogusławski, Mieczysław Künstler, Krystyna Łyczkowska, Stanisław Piłaszewicz (jako członkowie).

${ }^{23}$ Kopia wykładu habilitacyjnego doc. dra Jana Braun jest zachowana w Archiwum Uniwersytetu Warszawskiego, akta przewodów habilitacyjnych, sygn. WNF-hab2/88, k. 81-84. 
prac naukowych zatytułowaną Euscaro-Caucasica, która zawierała Jego najważniejsze prace poświęcone problematyce pokrewieństwa języków kartwelskich i języka baskijskiego ${ }^{24}$.

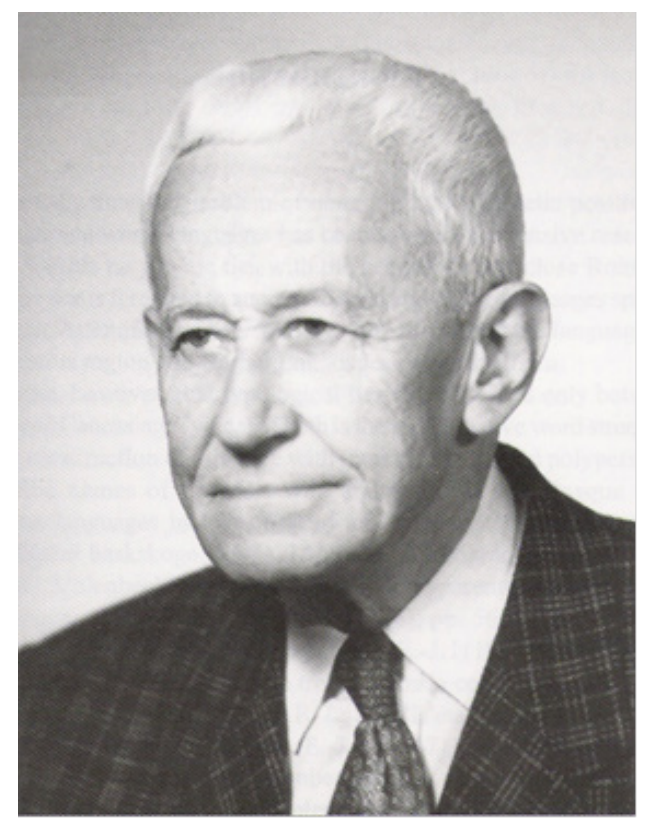

Ilustr. 4. Dr hab. prof. UW Jan Braun (1926-2015).

Źródło: Braun 1998: wkładka.

Trzy miesiące po habilitacji (28 VIII 1991 r.) Jan Braun wystąpił z wnioskiem o przejście na emeryturę od dnia 28 września 1991 w związku z osiągnięciem 65 roku życia. Rektor Uniwersytetu Warszawskiego przychylił się do powyższej prośby, ale nie chciał poprzeć wniosku kierownika jednostki i dziekana Wydziału Neofilologii o zatrudnienie świeżo upieczonego emeryta na umowę o dzieło. Ostatecznie jednak dr hab. Jan Braun został zatrudniony na czas określony w wymiarze $9 / 10$ etatu. Co ciekawe, pracował w takim nietypowym wymiarze aż do 30 września 2000. W roku akademickim 2000-2001 oraz ponownie 2001-2002 został zatrudniony na cały etat $\mathrm{w}$ ramach umowy o pracę (aż do 31 grudnia 2002). Po zakończeniu obowiązków dydaktycznych dr hab. prof. UW Jan Braun nie tylko nie zaprzestał działalności naukowej, ale nawet ją zintensyfikował i rozszerzył o nowe, wyją̧tkowo rozległe horyzonty badawcze. Powrócił także do podejmowanej w Uniwersytecie Łódzkim problematyki pochodzenia Etrusków i genezy ich języka (Braun 2007; 2009: 9-12).

${ }^{24}$ Braun 1998a. Publikacja liczy ogółem 147 stronic. 
Jan Nepomucen Józef Braun (1926-2015), filolog klasyczny, orientalista, kartwelista... 215

Zakres prac badawczych prof. Brauna jest zaiste przeogromny. Jako kartwelista był propagatorem literatury i kultury gruzińskiej ${ }^{25}$, stałym konsultantem naukowym w zakresie języka gruzińskiego ${ }^{26}$, między innymi w zakresie rękopisów ${ }^{27}$, literatury gruzińskiej i nazewnictwa kaukaskiego, zwłaszcza gruzińskiego ${ }^{28}$. Zajmował się przede wszystkim językiem i literaturą gruzińską ${ }^{29}$, a badał także rekonstruowany język prakartwelski ${ }^{30}$. Języki południowokaukaskie (kartwelskie) zestawiał z językiem baskijskim ${ }^{31}$ i był głęboko przekonany, że Baskowie są ludem najbliżej spokrewnionym z Gruzinami i innymi ludami kartwelskimi (Braun 1993: 35-43). Za swoje wybitne osiągnięcia naukowe z zakresu kartwelistyki prof. Jan Braun został uhonorowany medalem Akademika Ivane Dżawachiszwili, nadanym przez Rektora Uniwersytetu w Tbilisi (1976), oraz dożywotnim członkostwem Gruzińskiej Akademii Nauk jako współpracownik zagraniczny (od 2002 r.). Otrzymał ponadto doktorat honoris causa Tbiliskiego Uniwersytetu Państwowego (2007) oraz prestiżową nagrodę im. św. Grzegorza Peradze (2014) ${ }^{32}$.

Warto w tym miejscu odnotować, że prof. Braun zaklasyfikował język baskijski (często uznawany za izolowany) jako zachodni odprysk kartwelskiej (południowokaukaskiej) rodziny językowej, zepchnięty przez inwazję ludów indoeuropejskich w górskie regiony Pirenejów. W tej sugestii polski badacz nie był prekursorem, jako że hipoteza pokrewieństwa baskijsko-kaukaskiego zyskała znaczną popularność w literaturze przedmiotu począwszy od lat dwudziestych XX wieku ${ }^{33}$. Lingwiści, preferujący takie rozwiązanie, przytoczyli szereg podobieństw typologicznych baskijsko-kaukaskich i wiele zestawień leksykalnych. Należy jednak odnotować, że tzw. języki kaukaskie nie są genetycznie jednolite, lecz tworzą trzy osobne rodziny językowe:

(1) północnozachodniokaukaską (czyli abchaskoadygijską) ${ }^{34}$;

(2) północnowschodniokaukaską (czyli nachskodagestańską) ${ }^{35}$;

(3) południowokaukaską (czyli kartwelską).

${ }^{25}$ Roszko, Braun 1962: 111-175. Jan Braun przygotował też około 20 haseł, dotyczących literatury gruzińskiej, dagestańskiej, kabardyńskiej i osetyńskiej, które ukazały się drukiem w Małym stowniku pisarzy świata (Hanulak, Olszewski 1972).

${ }^{26}$ Por. np. Rustaweli 1966 (tu, konsultacja filologiczna: Jan Braun); Lang 1972 (tu, konsultant Jan Braun); Curtaweli 1999 (tu, konsultacja filologiczna J. Braun).

27 Zob. Roszko, Braun 1958.

${ }_{28}$ Zob. Dawitaj 1972. (J. Braun dokonał konsultacji nazw i terminów gruzińskich).

${ }^{29}$ Braun 1964a: 455; 1964b: 457; 1998b: 148-150; 2002-2003: 19-35.

${ }^{30}$ Braun 1965: 457; 1991-1992: 7-9; 2008; 2009: 5-14.

${ }^{31}$ Braun 1954: 40-42; 1981: 213-219; 1985: 875-879; 1988a: 227-232; 1988b: 38-41; 1988c: 85-89; 1994b: 77-85; 1998a; 2001b: 5-12.

32 Zob. Drewnowska 2018: 134. Warto odnotować, że Jan Braun uzyskał też polskie odznaczenia państwowe, m.in. Złoty Krzyż Zasługi (1975), Krzyż Kawalerski Orderu Odrodzenia Polski (1983), Złotą Odznakę ZNP (1984).

${ }^{33}$ Por. Uhlenbeck 1924: 565-588; Trombetti 1925; Bouda 1950: 207-232; Lafon 1951: 227-224.

34 Szerzej o tej rodzinie rozprawia Hewitt 2005: 91-145.

${ }^{35}$ Van den Berg 2005: 147-190. Do tej rodziny językowej niektórzy badacze zaliczają także języki hurro-urartyjskie, por. Diakonoff, Starostin 1986; 1988: 164-208. Należy jednak odnotować, że ta hipoteza spotkała się z gwałtowną krytyką ze strony zachodnioeuropejskich linguistów. 
Pojawiła się wprawdzie hipoteza badawcza o dalekim pokrewieństwie języków abchasko-adygijskich oraz języków nachsko-dagestańskich, które tworzą jakoby prastarą północnokaukaską wspólnotę językową (Nikolayev, Starostin 1994), ale hipoteza ta nie zyskała zwolenników w gronie kaukazologów, choć została podtrzymywana przez tzw. makrokomparatystów, którzy zakładają pokrewieństwo języków północnokaukaskich z innymi rodzinami językowymi lub językami izolowanymi ${ }^{36}$. Wszyscy badacze podkreślają zgodnie, że języki kartwelskie ani z rodziną abchaskoadygijską, ani nachskodagestańską nie są genetycznie spokrewnione. Ostatnio przeważa opinia makrolingwistów, że język baskijski może być genealogicznie pokrewny językom północnokaukaskim ${ }^{37}$, ale nie kartwelskim. Hipoteza prof. Jana Brauna o pokrewieństwie baskijsko-kartwelskim pozostaje zatem w opozycji do większości kaukazologów oraz makrokomparatystów, ale nie można o niej powiedzieć, że została całkowicie zdyskredytowana. Przyszłość pokaże, czy baskijski istotnie pozostaje w jakiejś genetycznej relacji z językami kaukaskimi (zarówno północnokaukaskimi, jak i południowokaukaskimi), gdyż wielu baskologów zgłasza poważne wątpliwości w odniesieniu do wartości tych relacji ${ }^{38}$.

Jako specjalista od Wschodu Starożytnego dr hab. prof. UW Jan Braun zajmował się licznymi wymarłymi językami z terenu Małej Azji i Bliskiego Wschodu ${ }^{39}$, między innymi językiem hatyckim (Braun 1994a: 15-23; 2003: 55-56), huryckim (Braun 1971c: 73-76), urartyjskim (Braun, Klimov 1954: 49-52), karyjskim (Braun 1995: 41-52), kasyckim (Braun 2009a) oraz sumeryjskim ${ }^{40}$. Próbował zaklasyfikować te języki (zazwyczaj uważane za języki izolowane) do znanych rodzin językowych. Pierwszym rzędzie uznawał język hatycki (używany w II tysiącleciu na terenie północno-zachodniej Anatolii) za najdawniej poświadczonego reprezentanta rodziny abchaskoadygijskiej (czyli północnozachodniokaukaskiej rodziny językowej). Tego typu hipoteza badawcza, podbudowana typologicznym podobieństwem wspomnianych języków, była wcześniej rozwijana przez lingwistów rosyjskich ${ }^{41}$.

Prof. Braun przedłożył hipotezę badawczą, że lud Kasytów, który przez kilka wieków władał Mezopotamią (ok. 1600-1100 p.n.e.), posługiwał się językiem na-

${ }^{36}$ Makrokomparatyści zestawili języki północnokaukaskie, sinotybetańskie, jenisejskie i na-dené oraz dwa języki izolowane (baskijski i buruszaski) w osobną makrorodzinę zwaną sino-kaukaską lub dené-kaukaską, por. Starostin 1991: 12-41; Blažek, Bengtson 1995: 11-50, 161-164; Bengtson 2008: 45-118.

37 Chirikba 1985: 95-105; Bengtson 1999: 41-57.

${ }^{38}$ Por. np. Míchelena 1968: 1414-1437; Trask 1995: 3-82. Przegląd rozmaitych (najczęściej rozbieżnych) teorii pochodzenia Basków i ich języka prezentuje Trask 1996: 358-414.

39 Zob. Braun 1971: 46-49. Warto także odnotować, że prof. Braun jest autorem licznych haseł dotyczących Mezopotamii i Sumerów, opublikowanych w trzynastotomowej Wielkiej Encyklopedii Powszechnej PWN, Warszawa 1962-1970.

${ }^{40} \mathrm{Z}$ zakresu sumerologii odnotujemy następujące pozycje: Braun 1964: 31-36; 1971b: 50-57; $2001 b ; 2004$.

${ }^{41}$ Dunaevskaya 1960: 73-77; V.G. Ardzinba 1974: 10-15; 1979: 26-37; Ivanov 1985: 26-59. 
Jan Nepomucen Józef Braun (1926-2015), filolog klasyczny, orientalista, kartwelista... 217

leżącym do rodziny drawidyjskiej. Należy odnotować, że stosunki pokrewieństwa języka kasyckiego są całkowicie niejasne ${ }^{42}$. Badacze stanowczo odrzucają semicki charakter języka kasyckiego, a zarazem kwestionują pokrewieństwo Kasytów z ludnością indoirańską i elamicką. Ostatnio próbuje się zestawiać język kasycki z językami hurrycko-urartyjskimi ${ }^{43}$. Skojarzenie języka kasyckiego z rodziną drawidyjską, proponowane przez prof. Brauna, jest kolejną próbą rozwiązania wyjątkowo trudnego problemu.

Prof. Braun usiłował m.in. wykazać, że silne koligacje łączą język Sumerów z językiem starotybetańskim i birmańskim, zatem należy go zaliczyć do tybetobirmańskiego ugrupowania rodziny sinotybetańskiej. Przygotowywał nawet rozprawę habilitacyjną pt. Język sumeryjski i języki tybeto-birmańskie, która w roku 1966 miała być bliska ukończenia ${ }^{44}$. Zamierzał także przygotować słownik etymologiczny języka sumeryjskiego, dokumentujący związki sumeryjsko-tybetobirmańskie, lecz do stworzenia takiej publikacji nigdy nie doszło ${ }^{45}$.

Prof. Braun już w czasach studenckich próbował wyświetlić pochodzenie Etrusków na podstawie źródeł archeologicznych. W późniejszym czasie usiłował rozwiązać zagadnienie genezy ich języka. Jego zdaniem, Etruskowie przybyli na Półwysep Apeniński ze wschodu (konkretnie z Anatolii), dlatego też język etruski ma charakter anatolijski i wykazuje szczególne zbieżności z językiem luwijskim (i pochodnymi odeń językami), choć zapewne wchłonął też obce elementy substratowe (przede wszystkim pelazgijsko-trackie). Tym samym prof. Braun zaliczył język etruski do indoeuropejskiej rodziny językowej.

Badania nad językami izolowanymi takimi jak język baskijski, etruski, hatycki, kasycki czy sumeryjski są wyjątkowo trudne, ponieważ te „zagadkowe” i izolowane języki nie wykazują oczywistych i bezspornych związków z otaczającymi je językami. Prof. Braun podejmował bez wahania trudne problemy etnolingwistyczne i proponował hipotezy najbardziej - Jego zdaniem - prawdopodobne. Przyszłość pokaże, czy Jego propozycje zyskają poklask i większe grono zwolenników.

Dr hab. prof. UW Jan Nepomucen Józef Braun (1926-2015) zmarł po ciężkiej chorobie w poniedziałek 29 czerwca 2015 roku. Pogrzeb uczonego odbył się w poniedziałek 6 lipca 2015 roku na Cmentarzu Powązkowskim w Warszawie.

${ }^{42}$ Delitzsch 1884; Balkan 1954; Jaritz 1957: 850-898; Ancilotti 1980.

${ }_{43}$ Schneider 2003: 372-381; Fournet 2011: 1-19. Do tej hipotezy przychyla się również Sassmannshausen 2014: 165-199.

${ }^{44}$ Archiwum Uniwersytetu Warszawskiego, Akta personalne, sygn. k 25915. Teczka osobowa Jana Józefa Brauna zawiera opinię o stanie zaawansowania pracy habilitacyjnej dra Jana Brauna (z 24 stycznia 1966 roku), podpisaną przez prof. Stefana Strelcyna, kuratora Katedry Filologii Starożytnego Wschodu.

${ }^{45}$ Doc. dr. Jan Braun, występując o urlop naukowy w roku akademickim 1984/1985, argumentował, że zamierza go wykorzystać ,dla zakończenia prac na słownikiem etymologicznym języka sumeryjskiego i niektórych innych drobniejszych prac". Rektor Uniwersytetu Warszawskiego przychylił się do tej prośby. 
O godzinie 12 w kościele św. Karola Boromeusza na Powązkach rozpoczęła się msza święta za zmarłego, po której nastąpił uroczysty pochówek. Jan Braun spoczął w grobie rodzinnym na zabytkowej nekropolii, zwanej zwyczajowo Starymi Powązkami.

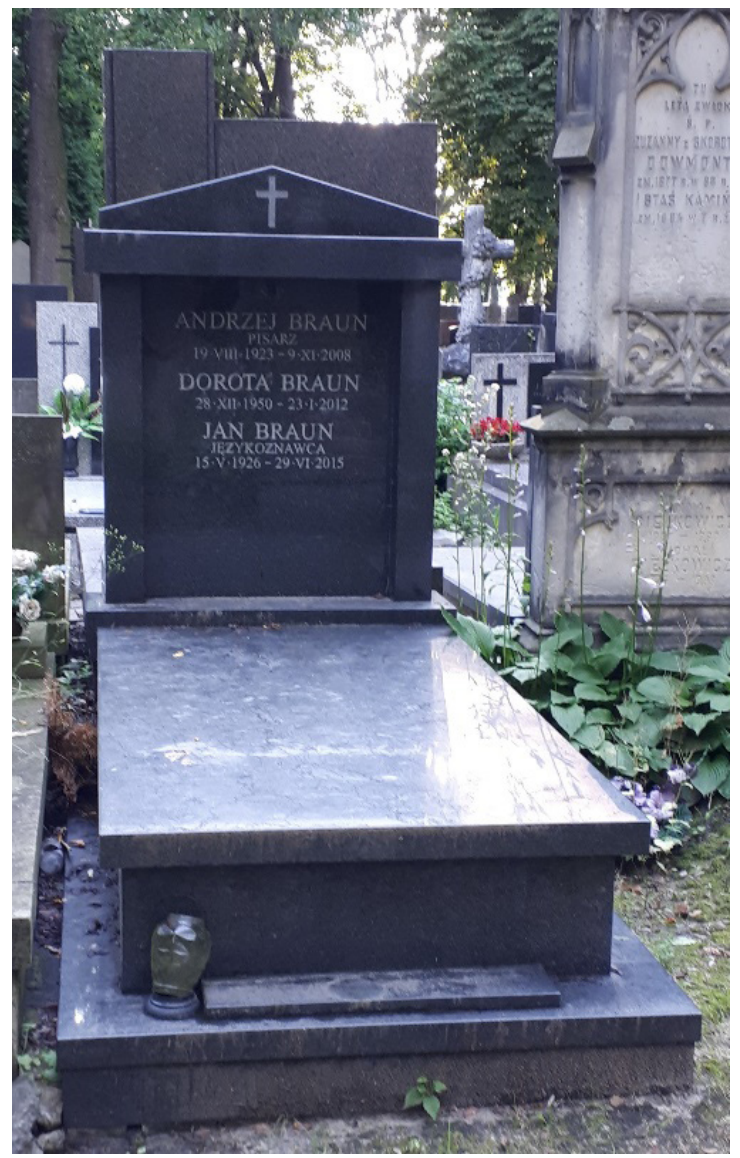

Ilustr. 5. Nagrobek braci Andrzeja i Jana Braunów na Cmentarzu Powązkowskim w Warszawie (kwatera 51-1-5).

Źródło: Fotografia autora. K.T. Witczak (3.07.2020). 
Jan Nepomucen Józef Braun (1926-2015), filolog klasyczny, orientalista, kartwelista... 219

Apendyks 1. Wykład habilitacyjny doktora Jana Brauna

\section{PODSTAWOWE PROBLEMY BADAŃ HISTORYCZNO-PORÓWNAW- CZYCH NAD JĘZYKAMI STAROŻYTNEGO ŚRÓDZIEMNOMORZA}

Niniejszy tekst zawiera wykład habilitacyjny dra Jana Brauna wygłoszony podczas kolokwium habilitacyjnego na posiedzeniu Rady Wydziału Neofilologii Uniwersytetu Warszawskiego w dn. 28 maja 1991 r. Tekst wystąpienia zachował się w materiałach postępowania habilitacyjnego prof. Jana Brauna w formie maszynopisu ${ }^{46}$. Artykuł dostosowano do aktualnie obowiązujących norm ortograficznych i obecnie używanej terminologii specjalistycznej, a ponadto w kilku miejscach wprowadzono drobne poprawki, usuwając typowe błędy wynikające z niewłaściwego odczytu tekstu przez osobę przepisującą wystąpienie lub je streszczającą. Wszystkie zmiany zostały każdorazowo wskazane w aparacie krytycznym. Dodano też objaśnienia i komentarze w formie przypisów.

\section{Wyklad habilitacyjny}

Europa do niedawna miała bardzo nikłe pojęcie o innych niż klasyczne językach używanych w starożytności w basenie Morza Śródziemnego. A przecież, poza greką i łaciną, występowało na tym obszarze bardzo wiele języków. Należały one do różnych rodzin językowych.

Ostatnie 50 lat zaznacza się istotnym postępem w badaniach nad wszystkimi językami tego obszaru. Przedstawię główne problemy oraz skrótowy opis tych języków w układzie geograficznym wschód - zachód, poczynając od Azji Mniejszej, poprzez Egeę, Bałkany, Italię aż po Hiszpanię.

Poczynając od Azji Mniejszej, [czyli] Anatolii - rewolucją w dotychczasowej wiedzy było odkrycie w czasach I wojny światowej języka hetyckiego. Nie domyślano się dotąd istnienia w II tys. p.n.e. na tym obszarze tak starego, odrębnego języka. Kiedy udało się Bedřrichowi Hroznemu odczytać w tekstach klinowych język indoeuropejski, indoeuropeiści poczuli się bardzo zaskoczeni. Nasze pojęcie o rodzinie języków indoeuropejskich do I wojny światowej kształtowało się na bazie sanskrytu, greki klasycznej, łaciny, a także języków starogermańskich. Dzięki badaniom historyczno-porównawczym XIX i XX wieku nad językami indoeuropejskimi stworzono obraz prajęzyka indoeuropejskiego. Tymczasem dane języka hetyckiego zmusiły badaczy do rewizji tradycyjnych poglądów.

${ }^{46}$ Archiwum Uniwersytetu Warszawskiego, akta przewodów habilitacyjnych, sygn. WNF-hab2/88, k. 81-84. 
Wykzad habilitacyjny dra Jana Brauna

wygzoszony podozas kolokwium habilitacyjnego na posiedzeniu Rady wydziału Neofilologii UW

$$
w \text { dn. } 28 \cdot 05 \cdot 1991 x \text {. }
$$

"podstawowe problemy badań historyczno-porównawezych nad językami starożytnego Sródziemnomorza"

Europa do niedawna miała bardzo nikłe pojęcie o innych niż klasyczne językach używanych w starożytności w basenie Morza Śródziemn._... ego. A przecié, poza greką i laciną, występowało na tym obszarze bardzo wiele języków. Należały one do różnych rodzin językowych.

Ostatnie 50 lat zaznacza się istotnym postepem w badaniach nad wszystkimi językami tego obszaru. Przedstawię gzówne problemy oduz skrótowy opis tych języków w układzie geograficznym wschód - zachód, poczynając od Azji 1niejszej poprzez Bgeę, Bałkany, Italię aż po Hiszpanię.

Poczynając od Azji Nniejszej, Anatolii - rewolucją w dotychczasowaj wiedzy było odkrycie w czasach I wojny światowej języka hetyckiego. Nie domyślano się dotąd istnienia w II tys.p.n.e. na tym obszarze tak starego, odrębnego jezyka. Kiedy udaxo sie Bedrichowi Hroznemu odczytać w tekstach klinowych języls indoeuropejski, indoeuropeiści poczuli się bardzo zaskoczeni. Nasze pojęcie o rodzinie języków indoeuropejskich do I wojny swiatowej kształtowało się na bazic sanskrytu, greki-klasycznej, laciny, a także języków starogermańskich. Dzięki badaniom bistoryczno-porównawc zym XIX $i \mathrm{XX}$ wielku nad jezykami indoeropejskimi stworzono obraz prajęzyka indoeuropejskiego. Tymezasem dane jezyka hetyckiego zmusiły badaczy do rewizji tradycyjnych poglądów.

Jeśli chodzi o języki anatolijskie występujące w II tys.p.n.e. w Azji llniejszej należy dodać, że ich specyficzne, archaiczne cechy różnią je wyraźnie od pozostałych języków indoeuropejskioh. W strukturze fonologicznej wcześniej poznanych języków indoeuropejskich many triady spółgłoskowe: dźwięczna, dźwięczna-

Ilustr. 6. Strona tytułowa maszynopisu.

Źródło: Archiwum Uniwersytetu Warszawskiego, akta przewodów habilitacyjnych, sygn. WNF-hab2/88, k. 81 . 
Jeśli chodzi o języki anatolijskie występujące w II tys. p.n.e. w Azji Mniejszej, [to] należy dodać, że ich specyficzne, archaiczne cechy różnią się wyraźnie od pozostałych języków indoeuropejskich.

W strukturze fonologicznej wcześniej poznanych języków indoeuropejskich mamy triady spółgłoskowe: dźwięczna, dźwięczna przydechowa i bezdźwięczna. W miejsce dawnej triady spółgłosek zwartych wykształcił się w językach anatolijskich nowy system, w którym spółgłoski słabe - lenes przeciwstawiają się spółgłoskom mocnym - fortes. Widoczne są także archaizmy w dziedzinie morfologii. Występuje jedynie genus commune - wspólny dla rodzaju męskiego i żeńskiego ${ }^{47}$ - dotyczący ludzi i bogów, zaś reszta jest określana jak genus neutrum. Budził ten układ wiele problemów, mówiono o zubożeniu morfologii, a był to po prostu starszy stan języka. W języku hetyckim zachował się najstarszy podział verbum. Verba actionis charakteryzują się koniugacją na -mi, zaś verba status koniugacją na -hii. Badania struktury języków anatolijskich pogłębiły naszą znajomość prajęzyka indoeuropejskiego.

W II tys. p.n.e. w Azji Mniejszej obok hetyckiego, czyli nesyckiego, występowały też inne języki indoeuropejskie tej samej grupy: luwijski i palajski. Potem się okazało, że potomkami języków anatolijskich z II tys. p.n.e. były tzw. języki późnohetyckie, używane w I tys. p.n.e. obok języka greckiego [na obszarze Azji Mniejszej]. Do grupy języków późnohetyckich zaliczamy obecnie: cylicyjski, licyjski $^{48}$, karyjski i lidyjski.

W III tys. p.n.e. niektóre języki anatolijskie dotarły do Grecji. Ślady ich są widoczne w tzw. przedgreckich nazwach geograficznych, np. Parnas, Samos. Ludność przedgrecka posługiwała się kilkoma językami: pelazgijskim, minojskim, lelegijskim i tyrseńskim ${ }^{49}$.

Przesuwając się bardziej na zachód, do Italii, docieramy do terenów, gdzie mówiono w I tys. p.n.e. językiem etruskim. Także w przypadku tego języka można ustalić strukturalne powiązania gramatyczne z językami anatolijskimi. Przy badaniach nad tym językiem stosowano dwie metody: kombinatoryjną ${ }^{50}$ i etymologiczną.

Nową dziedziną w badaniach nad językami rejonu egejskiego jest filologia mykeńska ${ }^{51}$, badająca pismo linearne B, odczytane już [w roku 1952] przez an-

${ }^{47}$ Genus commune jest zwykle określany jako „rodzaj żywotny” (Popko 1999: 62) lub „rodzaj osobowo-żywotny" (Danka 1986: 294).

${ }^{48} \mathrm{~W}$ polskiej literaturze przedmiotu pojawia się także alternatywne miano ,język likijski”. Jan Braun pomija tu drobniejsze języki Anatolii słabiej poświadczone w antycznej epigrafice, m.in. język milyjski (uważany niekiedy za dialekt licyjskiego), sidecki, a także pizydyjski (Popko 199: 111-116).

${ }^{49}$ Autor wykładu nie definiuje tych języków. Należy jednak podkreślić, że przynajmniej dwa określenia (,język pelazgijski” oraz ,język tyrseński”) stosuje w swoich późniejszych pracach, zob. Braun 2007; 2009: 9-12.

${ }^{50} \mathrm{~W}$ maszynopisie: kombinatoryczną.

${ }^{51} \mathrm{~W}$ maszynopisie: filologia myceńska. 
gielskiego uczonego [Michaela] Ventrisa. Udowodnił on, że język ten ${ }^{52}$ to grecki, zapisywany już od XV w. p.n.e. ${ }^{53}$ Pozwala to przedłużyć historię języka greckiego o 700 lat.

Nowsze odkrycia pozwoliły określić jeszcze jedną grupę języków indoeuropejskich na Półwyspie Bałkańskim - grupę dako-myzyjską. Używana ona była na pograniczu dzisiejszej Bułgarii i Serbii. Języki tej grupy mają odrębny system fonologiczny i morfologiczny, różnią się wyraźnie od języka trackiego i iliryjskiego.

Mało poznana pozostaje grupa iliryjska występująca na obszarze dzisiejszej Jugosławii i Albanii. Znana jest dzięki zachowanym antroponimom i toponimom w napisach greckich i rzymskich.

Przechodzę [teraz] do Półwyspu Apenińskiego ${ }^{54}$. Mamy tu trzy odrębne grupy języków indoeuropejskich: praitalską, której ślady widoczne są w łacinie i innych językach ${ }^{55}$; latyńską, związaną z obszarem Lacjum wokół Rzymu oraz trzecią, oskijsko-umbryjską, czyli języki Osków i Umbrów. Grupa łacińska dzieliła się na trzy języki: łaciński, ausoński i sykulski ${ }^{56}$. Nie został określony także jeszcze do końca charakter języka wenetyjskiego, którym mówiono na terenach położonych na zachód i północ od dzisiejszej Wenecji. Ma on dużo wspólnego z językami indoeuropejskimi Italii, wykazuje jednak pewne związki z językami germańskimi.

Najdalej na zachód, na terenie Hiszpanii, występował indoeuropejski język Celtiberów, którego inskrypcje alfabetyczne pochodzące od V do I w. p.n.e. są dziś odczytane przez celtologów ${ }^{57}$.

Tyle można powiedzieć o językach indoeuropejskich. Natomiast na obszarze Hiszpanii mamy jeszcze język baskijski, wiązany z językami kaukaskimi. Poza obszarem Pirenejów, gdzie występował język baskijski, Hiszpanię środkową i południową zajmowali Iberowie. Pozostał po nich cały szereg napisów alfabetycznych, powstałych w oparciu o alfabet fenicki, z okresu od VI do I w. p.n.e. Napisy

${ }^{52}$ Konkretnie chodzi tu o język inskrypcji zapisanych pismem linearnym B. Było ono używane w strefie egejskiej w drugiej połowie II tysiąclecia p.n.e.

${ }^{53}$ Inskrypcje zapisane pismem linearnym B datuje się zazwyczaj na XIV-XII w. p.n.e.

${ }^{54}$ W maszynopisie: Półwyspu Italskiego.

${ }^{55}$ Jan Braun zaliczył wcześniej język etruski do grupy anatolijskiej języków indoeuropejskich. W tym jednak miejscu o egzystencji grupy anatolijskiej na Półwyspie Apenińskim nie wspomina ani słowem. Nie ma pewności, co autor rozumie pod pojęciem grupy praitalskiej i czy zalicza do niej język etruski, wenetyjski lub liguryjski. Niewykluczone, że w obrębie grupy praitalskiej Jan Braun umieszcza nieitalski język mesapijski, używany na terenie Apulii, po którym pozostała spora liczba połowicznie zrozumiałych inskrypcji.

${ }^{56}$ Autor wystąpienia pomija w tym zestawieniu język faliski, być może przyjmując hipotezę badawczą, że jest to peryferyjny dialekt języka łacińskiego. W dobie współczesnej język ten powszechnie uznaje się za samodzielną jednostkę, całkowicie odrębną od łaciny (Leszkiewicz 2017).

57 Jan Braun stosuje przypuszczalnie nazwę ,jęzzyk Celtiberów" na określenie wszystkich grup indoeuropejskich występujących na obszarze Półwyspu Iberyjskiego. Współczesna nauka wydziela na tym obszarze kilka osobnych jednostek etnicznych, posługujących się odrębnym pismem i odmiennym językiem. Obecnie wydziela się jako swoiste idiomy m.in. język iberoceltycki, luzytański oraz tartezyjski. 
Jan Nepomucen Józef Braun (1926-2015), filolog klasyczny, orientalista, kartwelista... 223

te zostały odczytane w XX wieku przez uczonych hiszpańskich, ale język, który jest w nich zawarty, tzn. język iberyjski, nie można jeszcze w chwili obecnej zaliczyćs $^{58}$ do żadnej ze znanych obecnie rodzin językowych. Do języka iberyjskiego można odnieść prawdopodobnie także przedromański język sardyński na wyspie Sardynii oraz język sykański używany w zachodniej części Sycylii. Trudno powiedzieć coś określonego o związkach genetycznych języka liguryjskiego używanego w starożytności w północno-wschodniej Italii i południowej Francji.

Wreszcie na zakończenie [wypowiem] kilka słów o najstarszych stosunkach językowych krajów położonych na obszarze Afryki północnej, przylegającym do wybrzeży Morza Śródziemnego. Występowały tu już od epoki neolitu języki semicko-chamickiej ${ }^{59}$ rodziny językowej: staroegipski, berberyjski. W formie pisemnej język staroegipski zaświadczony jest przez bogatą literaturę starożytnego Egiptu. Natomiast starożytną odmianę języka berberyjskiego poznać możemy poprzez inskrypcje $\mathrm{w}$ języku numidyjskim, zachowane z obszarów pogranicznych Tunezji i Algierii, z dwóch ostatnich wieków p.n.e.

Pragnę więc [moje wystąpienie] zakończyć stwierdzeniem, że na obszarze starożytnego Śródziemnomorza spotykamy języki należące do różnych rodzin językowych: indoeuropejskiej, kaukaskiej ${ }^{60}$ i semito-chamickiej oraz do bliżej jeszcze nieokreślonej grupy autochtonicznej, którą reprezentował język iberyjski ${ }^{61}$.

Tekst do druku przygotował Krzysztof Tomasz WITCZAK

\section{Bibliografia}

Ancilotti, A. (1980). La lingua dei Cassiti. Milano: Unicopli.

Ardzinba, V.G. (1974). Some Notes on the Typological Affinity Between Hattian and North-West Caucasian (Abkhazo-Adygian) Languages. W: Komoróczy, G., Gaál, E. (red,) International Tagung der Keilschriftforscher der sozialistischen Länder. Budapest, 23.-25. April 1974. Zusammenfassung der Vorträge. Budapest: Eötvös Loránd Tudományegyetem. 10-15.

Ardzinba, V.G. (1979). Nekotorye skhodnye strukturnye priznaki khattskogo i abkhazo-adygskikh yazykov. W: Peredneasiatskii Sbornik III: istoriya i filologiya stran drevnego vostoka. Moskva: Izdatelstvo "Nauka". 26-37.

${ }^{58}$ W maszynopisie: odnieść.

${ }^{59}$ W maszynopisie: semickiej.

${ }^{60}$ Nie istnieje jednolita „kaukaska” rodzina językowa. Na terenach przykaukaskich wyróżnia się 3 osobne rodziny językowe: (1) abchaskoadygijską, zwaną inaczej północnozachodniokaukaską; (2) nachskodagestańską, zwaną także północnowschodniokaukaską; (3) południowokaukaską, czyli kartwelską (Klimov 1994). Oprócz tych trzech rodzin językowych znajdziemy też w strefie przykaukaskiej przedstawicieli rodziny indoeuropejskiej, należących do grupy paleobałkańskiej (Ormianie) i indoirańskiej (Osetyńcy), a także reprezentantów grupy turkijskiej należącej do ałtajskiej rodziny językowej (Azerowie, Turcy). Przypuszczalnie Jan Braun, mówiąc o rodzinie „kaukaskiej” na obszarze Środziemnomorza miał na myśli kartwelską (czyli południowokaukaską) rodzinę językową, do której - jego zdaniem - powinniśmy zaliczyć język baskijski.

${ }^{61} \mathrm{~W}$ maszynopisie: iliryjski. 
Balkan, K. (1954). Kassitenstudien. Band I. Die Sprache der Kassiten. New Haven: American Oriental Society.

Bengtson, J.D. (1999). „A Comparison of Basque and (North) Caucasian Basic Vocabulary”. Mother Tongue 5. 41-57.

Bengtson, J.D. (2008). „Materials for a Comparative Grammar of the Dene-Caucasian (Sino-Caucasian) Languages". Aspects of Comparative Linguistics 3. 45-118.

Blažek, V., Bengtson, J.D. (1995). „Lexica Dene-Caucasica”. Central Asiatic Journal 39(1). 11-50; 39(2). 161-164.

Bouda, K. (1950). „L'Euskaro-Caucasique”. Boletín de la Real Sociedad Vasca de Amigos del País 3. 207-232.

Braun, J. (1954). Slovarnye skhozhdeniya baskskogo i kartvelskikh yazykov. W: VII naučnaja konferencija aspirantov Tbilisskogo gosudarstvennogo universiteta. Plan raboty i tezisy dokladov. Tbilisi: Izdatelstvo Tbilisskogo universiteta. 40-42.

Braun, J. (1955). Mnogolichnost (poliprozopiya) gruzinskogo glagola. Tbilisi: Izdatelstvo Tbilisskogo universiteta.

Braun, J. (1959). „Z poezji gruzińskiej”. Przegląd Orientalistyczny 2(30). 195-200.

Braun, J. (1964a). Gruzińska literatura. W: Wielka Encyklopedia Powszechna PWN. T. IV. Warszawa: Państwowe Wydawnictwo Naukowe. 455.

Braun, J. (1964b). Gruziński język, W: Wielka Encyklopedia Powszechna PWN. T. IV. Warszawa: Państwowe Wydawnictwo Naukowe. 457.

Braun, J. (1964c). Pochodzenie języka sumeryjskiego. W: Strelcyn, S. et alii (red.). Sesja jubileuszowa XXX-lecia Instytutu Orientalistycznego Uniwersytetu Warszawskiego (21-22 I 1964), Komunikaty naukowe. Warszawa: Wydawnictwa Uniwersytetu Warszawskiego. 31-36.

Braun, J. (1965). Kartwelskie języki. W: Wielka Encyklopedia Powszechna PWN. T. V. Warszawa: Państwowe Wydawnictwo Naukowe. 457.

Braun, J. (1971a). Stosunki etniczne starożytnej Mezopotamii. W: Braun, J. (red.). Mezopotamia. Warszawa: Państwowe Wydawnictwo Naukowe. 46-49.

Braun, J. (1971b). Język sumeryjski. W: Braun, J. (red.). Mezopotamia. Warszawa: Państwowe Wydawnictwo Naukowe. 50-57.

Braun, J. (1971c). Język hurycki. Braun, J. (red.). Mezopotamia. Warszawa: Państwowe Wydawnictwo Naukowe. 73-76.

Braun, J. (1981). Euscaro-Caucasica. W: Encuentros internacionales de vascologos. Bilbao: Real Academia de la Lengua Vasca. 213-219.

Braun, J. (1984), Baskologiis šesavali. Tbilisi: Tbilisis universițțis gamomcemloba.

Braun, J. (1985). Africadas de las lenguas kartvélicas y sus correspondencias regulares en el vasco. Observaciones adicionales. W: Melena, J.L. (red.). Symbolae Ludovico Mitxelena septuagenario oblatae. Vitoria Gasteiz: Universidad del País Vasco, Instituto de Ciencias de la Antigüedad. 875-879.

Braun, J. (1988a). Nomina verbalia en las lenguas kartvelicas y en el vasco. W: Il Congreso Mundial Vasco, Congreso de la lengua vasca. T. II. Vitoria Gasteiz: Eusko Jaurlaritzaren Argitalpen-Zerbitzu Nagusia. 227-232.

Braun, J. (1988b). The Grammatical Category of Article in Kartvelian and Basque. A Comparative Study. W: Thordarson, F. (red.). Studia Caucasologica I. Proceedings of the Third Caucasian Colloquium, Oslo 1986. Oslo: Oslo University Press. 38-41.

Braun, J. (1988c). Drevneishie formy kauzativa $v$ kartvelskikh yazykakh i $v$ baskskom. W: Materialy pervogo mezhdunarodnogo kartvelologicheskogo simpoziuma. Tbilisi: Izdatelstvo Tbilisskogo Universiteta. 85-89.

Braun, J. (1991-1992). „Proto-Kartvelian declension and its development”. Lingua Posnaniensis 34. 7-9.

Braun, J. (1993). „Kogda baski poteryali kontakt s ostalnymi kartvelskimi plemenami?”. Rocznik Orientalistyczny 48(2). 35-43. 
Jan Nepomucen Józef Braun (1926-2015), filolog klasyczny, orientalista, kartwelista... 225

Braun, J. (1994a). „Khattskii i abkhazo-adygskii”. Rocznik Orientalistyczny 49(1). 15-23.

Braun, J. (1994b). Nombres de los insectos en las lenguas kartvélicas y en el vasco. W: Orpustan, J.B. (red.), La langue basque parmi les autres. Actes du Colloque de l'URA 1055 du CNRS. Baigorri: Editions Izpegi. 77-85.

Braun, J. (1995). „Addenda Carica”. Rocznik Orientalistyczny 50(1). 41-52.

Braun, J. (1998a). Euscaro-Caucasica. Historical and Comparative Studies on Kartvelian and Basque. (Seria: Philologia Orientalis, Vol. 4). Warszawa: Wydawnictwo Akademickie Dialog.

Braun, J. (1998b). Vtorichnyi kharakter garmonicheskikh konsonantnykh kompleksov detsessivnogo ryada $v$ kartvelskikh yazykakh. W: Kvarac'xelia G. (red.). Materials of the International Symposium dedicated to the $100^{\text {th }}$ birth anniversary of Arnold Čikobava. Tbilisi: Tbilisskii Gosudarstvennyi Universitet im. I. Dzhawakhishwili. 148-150.

Braun, J. (2001a). Sumerian and Tibeto-Burman. Warszawa: Wydawnictwo Agade.

Braun, J. (2001b). „Verbos kartvélicos y vascos”. Fontes linguae Vasconum: Studia et documenta 33(86). 5-12.

Braun, J. (2002-2003). „Wieloosobowość czasownika w języku gruzińskim”. Pro Georgia 9-10. $19-35$.

Braun, J. (2003). Lokalnyje prefiksy khattskogo glagola i te zhe morfemy v abkhazo-adygskikh yazykakh. W: Taracha, P. (red.). Silva Anatolica. Anatolian Studies Presented to Maciej Popko on the Occasion of His 65th Birthday. Warszawa: Wydawnictwo Agade. 55-56.

Braun, J. (2004). Sumerian and Tibeto-Burman. Additional Studies. Warszawa: Wydawnictwo Agade. Braun, J. (2007). Luvian and Tyrsenian. Warszawa: Wydawnictwo Agade.

Braun, J. (2008). Protokartvelian. Warszawa: Wydawnictwo Agade.

Braun, J. (2009a). Kassite and Dravidian. Warszawa: Wydawnictwo Agade.

Braun, J. (2009b). Pelasgian and Thracian Personal Names in Tyrsenian Language. W: Drewnowska-Rymarz, O. (red.). Here and There across the Ancient Near East. Studies in Honour of Krystyna Lyczkowska. Warszawa: Wydawnictwo Agade. 9-12.

Braun, J. (2009c). „Protokartvelskii yazik”. Pro Georgia. Journal of Kartvelogical Studies 18. 5-14.

Braun, J., Klimov, G.A. (1954). Ob istoricheskom vzaimootnoshenii urartskogo i iberiisko-kavkazskikh yazykov. W: V (XI) nauchnaya sessiya Instituta yazykoznaniya Akademii Nauk Gruzinskoi SSR, 1954, 10, 11 i 12 Iyuniya. Tezisy dokladov. Tbilisi: Izdatelstvo Tbilisskogo universiteta. 49-52.

Chirikba, V.A. (1985). Baskskij i severokavkazskie jazyki, W: Piotrovskii, B.B., Ivanov, V.V., Ardzinba, V.G. (red.). Drevnyaya Anatoliya. Moskva: Izdatelstvo „Nauka”. 95-105.

Curtaweli, J. (1991). Męczeństwo świętej Szuszanik. Przeł. i wstępem opatrzył E. Biedka; konsultacja filologiczna J. Braun. Kraków: Miniatura.

Danka, I.R. (1986). Języki anatolijskie. W: Bednarczuk, L. (red.). Języki indoeuropejskie. T. I. Warszawa: Państwowe Wydawnictwo Naukowe.

Dawitaj, F.F. (red.). (1972). Zwiazek Radziecki. Gruzja. Praca zbiorowa. Tłumaczenie z rosyjskiego L. Baraniecki, konsultacja nazw i terminów gruzińskich J. Braun. Warszawa: Państwowe Wydawnictwo Naukowe.

Delitzsch, F. (1884). Die Sprache der Cossäer, linguistisch-historische Funde und Fragen. Leipzig: J.C. Hinrichs.

Diakonoff, I.M., Starostin, S.A. (1986). Hurro-Urartian as an Eastern Caucasian Languages. München: R. Kitzinger.

Diakonoff, I.M., Starostin, S.A. (1988). Khurrito-urartskie i vostochnokavkazskie yazyki. W: Drevnii Vostok. Etnokulturnye svyazi. Moskva: Izdatelstvo „Nauka“. 164-208.

Drewnowska, O. (2018). „Jan Braun (1926-2015). Obituarium”. Rocznik Orientalistyczny 71(1). 133-139.

Dunaevskaya, I.M. (1960). O strukturnom skhodstve khattskogo yazyka c yazykami severo-zapadnogo Kavkaza. W: Issledovaniya po istorii kultury narodov Vostoka. Sbornikv chest akademika N. A. Orbeli. Moskva-Leningrad: Akademiya Nauk SSSR. 73-77. 
Fournet, A. (2011). „The Kassite language in a Comparative Perspective with Hurrian and Urartean". The Macro-Comparative Journal 2(1). 1-19.

Hanulak, K.. Olszewski, H. (red.). (1972). Mały słownik pisarzy świata. Warszawa: Wiedza Powszechna.

Hewitt, G. (2005). „North West Caucasian”. Lingua 115. 91-145.

Ivanov, V.V. (1985). Ob otnoshenii khattskogo yazyka k severo-zapadnokavkazskim. W: Piotrovskii, B.B., Ivanov, V.V., Ardzinba, V.G. (red.). Drevnyaya Anatoliya. Moskva: Izdatelstvo „Nauka”. 26-59.

Jaritz, K. (1957). „Die kassitische Sprachreste”. Anthropos 52. 850-898.

Jędrzejczak, D., Pacho, Z. (2003). „Krótka historia Katedry Filologii Klasycznej Uniwersytetu Łódzkiego (1945-2003)". Collectanea Philologica 7. 71-85.

Kita, J., Pytlas, S. (2005). W stużbie nauki. Profesorowie Uniwersytetu łódzkiego w latach 19452004. Pro memoria. Łódź: Wydawnictwo Uniwersytetu Łódzkiego.

Klimov, G.A. (1994). Einführung in die kaukasische Sprachwissenschaft. Hamburg: Buske Verlag.

Kowalski, W. (2007). Przedwojenni nauczyciele Łodzi: wspomnienia i refleksje. Łódź: Wydawnictwo „Piktor”.

Kozłowski, M. (2017). „Leon Tadeusz Błaszczyk (30 III 1923-27 XII 2016) i Józef Edmund Mélèze-Modrzejewski (8 III 1930-29 I 2017)”. Nowy Filomata 21(2). 277-283.

Lafon, R. (1951). „Concordances morphologiques entre le basque et les langues caucasiques". Word 7. 227-224.

Lang, D.M. (1972). Dawna Gruzja. Przełożył W. Hensel. Konsultant J. Braun. Warszawa: PIW.

Leszkiewicz, B. (2017). Język faliski. Kraków: Wydawnictwo Uniwersytetu Jagiellońskiego.

Míchelena, L. (1968). L'euskaro-caucasien. W: Martinet, A. (red.). Le langage. Encyclopédie de la Pléiade. Paris: Gallimard. 1414-1437.

Nikolayev, S.L., Starostin, S.A. (1994). A North Caucasian Etymological Dictionary. Moscow: Asterisk Publishers.

Oświecimski, S. (1978). Oko Jan. W: Polski Słownik Biograficzny. T. XXIII. Wrocław: Zakład Narodowy im. Ossolińskich. 670-672.

Oziminkowski, V. (2014). Opowieść o pierwszej damie polskiej seksuologii: Michalina Wisłocka. Sztuka kochania gorszycielki. Warszawa: Prószyński Media.

Popko, M. (1999). Ludy i języki starożytnej Anatolii. Warszawa: Wydawnictwo Akademickie Dialog.

Roszko, K., Braun J. (1958). Katalog rękopisów orientalnych ze zbiorów polskich, t. 3: Katalog rękopisów ormiańskich i gruzińskich. Dział ormiański oprac. K. Roszko; dział gruziński oprac. J. Braun. Warszawa: Polska Akademia Nauk. Zakład Orientalistyki, Państwowe Wydawnictwo Naukowe.

Roszko, K., Braun, J. (1962). Pod Araratem i Kazbekiem: przysłowia, bajki, zagadki, wybrali i przełożyli z ormiańskiego i gruzińskiego K. Roszko, J. Braun. Warszawa: Wiedza Powszechna.

Roszko, K., Braun, J. (1967). Pod Araratem i Kazbekiem: przysłowia, bajki, zagadki, wybrali i przełożyli z ormiańskiego i gruzińskiego K. Roszko, J. Braun, wyd. 2 zmienione. Warszawa: Wiedza Powszechna.

Rustaweli, S. (1966). Wiciądz w tygrysiej skórze. Przekład fragmentów, trawestacje i słowo wiążące: J. Zagórski; konsultacja filologiczna: J. Braun, ilustr. J. Skarżyński. Kraków: Wydawnictwo Literackie.

Rządkiewicz, M.G. (2005). Łódzka filologia klasyczna w latach 1945-2005: Zarys dziejów i dokonań. Łódź: Uniwersytet Łódzki. (Praca magisterska napisana pod kierunkiem prof. dra hab. K.T. Witczaka w zbiorach Katedry Filologii Klasycznej UŁ).

Sassmannshausen, L. (2014). Kassitische Herrscher und ihre Namen. W: Sassmannshausen, L., Neumann, G. (red.). He Has Opened Nisaba's House of Learning. Studies in Honor of Ake Waldemar Sjöberg on the Occasion of His 89th Birthday on August 1st 2013. Leiden-Boston: Brill. 165-199.

Schneider, T. (2003). „Kassitisch und Hurro-Urartäisch. Ein Diskussionsbeitrag zu möglichen lexikalischen Isoglossen”. Altorientalische Forschungen 30. 372-381. 
Starnawski, J. (1998). Oko Jan. W: Starnawski, J. (red.). Stownik badaczy literatury polskiej, T. II. Łódź: Wydawnictwo Uniwersytetu Łódzkiego. 338-340.

Starnawski, J. (2003). „Jan Oko, pierwszy profesor filologii klasycznej Uniwersytetu Łódzkiego i piąty prezes Koła Łódzkiego PTF”. Collectanea Philologica 7. 87-90.

Starostin, S.A. (1991). On the Hypothesis of a Genetic Connection Between the Sino-Tibetan Languages and the Yeniseian and North Caucasian Languages. W: Shevoroskin, V.V. (red.). Dene-Sino-Caucasian languages: materials from the First International Interdisciplinary Symposium on Language and Prehistory. Ann Harbor-Bochum: Brockmeyer. 12-41.

Taracha, P. (2014). „Maciej Popko (1936-2014)”. Rocznik Orientalistyczny 67(2). 104-108.

Taracha, P., Głazek, G. (2014), „A Complete Bibliography of Maciej Popko”. Rocznik Orientalistyczny 67(2). 109-122.

Trask, R.L. (1995). „Basque and Dene-Caucasian: A Critique from the Basque Side”. Mother Tongue 1. 3-82.

Trask, R.L. (1996). History of Basque. New York-London: Psychology Press. 358-414.

Trombetti, A. (1925). Le origini della lingua basca. Bologna: Forni.

Tulisow, J. (2006). Rec. Braun (2004). Przeglad Orientalistyczny 3-4. 228-230.

Uhlenbeck, C.C. (1924). „De la possibilité d'une parenté entre le basque et les langues caucasiques”. Revue Internationale des Études Basques 15. 565-588.

Van den Berg, H. (2005). „The East Caucasian Language Family”. Lingua 115. 147-190.

Wisłocka, M. (1998). Malinka, Bratek i Jaś. Warszawa: Prószyński S-ka.

Prof. dr hab. Krzysztof Tomasz Witczak - Full Professor at the Chair of Classical Philology, Faculty of Philology, University of Lodz. His basic fields of interest are connected with Greek, Latin and Indo-European linguistics, as well as the history of classical philology in Poland. He also published a number of papers devoted to the Etruscan language.

Address: Uniwersytet Łódzki, Wydział Filologiczny, Katedra Filologii Klasycznej, Zakład Latynistyki i Językoznawstwa. ul. Pomorska 171/173, 90-236 Łódź. e-mail: krzysztof.witczak@uni.lodz.pl. 